\title{
ANALISIS BERPIKIR KOMPUTASI GURU SEKOLAH DASAR DALAM MENYELESAIKAN MASALAH TERKAIT SKALA
}

\author{
Computational Thinking Analysis of Elementary School Teacher in Solving Problem \\ Related to Scale
}

\author{
Sri Wulandari Danoebroto ${ }^{1 *}$ Choirul Listiani ${ }^{1)}$ \\ ${ }^{1}$ PPPPTK Matematika J1 Kaliurang Km 6 Depok Sleman, (0274)881717, 55281, Indonesia \\ *)wulanp4tkmatematika@gmail.com
}

\begin{abstract}
This study aims to analyze the problem solving strategy and computational thinking processes of elementary school teachers in solving problems related to scale. This research was a descriptive research. Data were collected with a mathematical competency test equivalent to National Base School Examination (USBN), then analyzed descriptively referring to the characteristics of computational thinking. The results of the study are: 1) the strategy used by the teacher in solving problems related to scale is making drawings / sketches that are equipped with information provided. However, mathematical models have not been presented communicatively, 2) Teacher'scomputational thinking in the decomposition element is in the good category and in the algorithm element is also in the good category. Errors occur because of incorrect calculation or lack of logical thinking in interpreting the relationship of information.
\end{abstract}

Keywords: Computational thinking, elementary school teacher, scale problem

\begin{abstract}
ABSTRAK
Penelitian ini bertujuan untuk menganalisis strategi pemecahan masalah dan proses berpikir komputasi guru SD dalam menyelesaikan masalah terkait skala. Penelitian ini merupakan penelitian deskriptif. Data dikumpulkan dengan tes kompetensi matematika setara USBN, kemudian dianalisis secara deskriptif mengacu pada karakteristik berpikir komputasi. Hasil penelitian adalah: 1) strategi yang digunakan oleh guru dalam menyelesaikan permasalahan terkait skala adalah membuat gambar/sketsa yang dilengkapi dengan informasi/ data yang diberikan. Namun, model/kalimat matematika belum ditampilkan dengan komunikatif, 2) Berpikir komputasi guru dalam unsur dekomposisi dalam kategori baik dan dalam unsur algoritma juga dalam kategori baik. Kesalahan terjadi karena keliru menghitung atau kurang berpikir logis dalam menafsirkan hubungan antar informasi.
\end{abstract}

Kata kunci: Berpikir komputasi, guru SD, masalah skala

\section{PENDAHULUAN}

Berpikir komputasi merupakan salah satu kecakapan berpikir yang dibutuhkan di Abad 21 ini. Kemampuan berpikir komputasi merujuk pada keterampilan untuk mengarahkan tindakan penyelesaian masalah melalui langkah-langkah yang sistematis. Langkah-langkah yang sistematis tersebut dilandasi oleh analisis masalah dan strategi pemecahan masalah yang tepat.

Ioannidou, et al (2011) menyatakan bahwa berpikir komputasi merupakan kemampuan berpikir tentang masalah dalam bentuk yang lebih abstrak sebagai jalan untuk mencapai penyelesaian yang kreatif. Kemampuan penting ini perlu dikuasai siswa agar dapat melihat lebih banyak solusi yang mungkin. Aplikasi berpikir komputasi dalam matematika lebih dikenal dengan nama berpikir algoritmik. Denning (2009) menyatakan bahwa berpikir algoritmik merupakan proses mental dalam merumuskan masalah sebagai konversi dari beberapa input menjadi sebuah output dan upaya mencari algoritma untuk menampilkan konversi ini. Istilah berpikir algoritmik ini kemudian diperluas mencakup berpikir pada beberapa tingkat abstraksi, menggunakan matematika untuk membangun algoritma dan menguji seberapa baik solusi untuk mengatasi masalah.

Karakteristik umum berpikir komputasi adalah abstraksi dan pemecahan masalah (Ioannidou, et al., 2011:4). Sementara menurut The International Society for Technology in Education (ISTE)dalam kolaborasinya dengan Computer Science Teachers Association (CSTA), karakteristik berpikir komputasi antara lain meliputi: 1) merumuskan masalah untuk digunakan bersama komputer dalam membantu mendapatkan solusi, 2) mengorganisasi secara logis dan menganalisis data, 3) menyajikan data melalui abstraksi, 4) otomasi solusi melalui proses algoritmik, 5) mengidentifikasi, menganalisis 
dan menerapkan solusi yang mungkin sebagai sumberdaya dan kombinasi tahap yang paling efisien dan efektif, 6) menggeneralisasi dan mentransfer proses ini kepada masalah atau wilayah lain yang bervariasi (ISTE, 2007).

Merujuk pada pendapat Ioannidou, et.al (2011) dan ISTE (2007), terdapat beberapa karakteristik berpikir komputasi yang berlaku di bidang matematika. Dalam matematika, terdapat proses abstraksi dan langkah pemecahan masalah secara algoritmik. Abstraksi dalam matematika merupakan proses mengubah kalimat sehari-hari menjadi kalimat matematika sehingga terdefinisikan dengan tepat (Mitchelmore \& White, 2004:329). Matematika mempunyai simbol, sintaks, dan tatabahasa sendiri serta beragam representasi, sehingga matematika dapat dipandang sebagai bahasa tersendiri (Rani, 2013:57). Matematika sebagai bahasa memiliki keunggulan dalam mengomunikasikan ide secara efektif dan efisien sehingga menghindari timbulnya penafsiran ganda. Bahasa semacam ini relevan dengan kebutuhan instruksi kepada mesin sebagaimana salah satu karakteristik berpikir komputasi sebagai perumusan masalah untuk diselesaikan berbantuan komputer.

Langkah pemecahan masalah dalam matematika menggunakan strategi algoritmik yang bertujuan agar dapat memperoleh solusi masalah menggunakan operasi dan representasi matematika (Rani, 2013:59). Representasi matematis berguna sebagai alat berpikir dan instrumen untuk mengkomunikasikan gagasan atau ide-ide matematika yang tertata baik dalam rangka memecahkan masalah. Representasi matematis dapat berupa, antara lain: grafik, diagram, sketsa, persamaan, tabel, formasi bilangan, simbol/lambang, kata-kata, gambar, manipulatif objek, dan berpikir tentang ideide matematika.

Algoritma juga melibatkan pemodelan matematis. Pyzara (2014:26) menyatakan bahwa merancang model matematika merupakan proses siklik dari masalah nyata ke dalam masalah matematika untuk kemudian diterjemahkan kembali dalam situasi nyata awal. Proses siklik ini menandai tahapan atau langkah pemecahan masalah dalam bentuk algoritma. Untuk dapat menyusun langkah pemecahan masalah, khususnya masalah yang kompleks, diperlukan upaya memecah persoalan menjadi beberapa bagian yang dapat atau perlu diselesaikan terlebih dahulu.

Berdasarkan uraian di atas, dapat disimpulkan bahwa berpikir komputasi dalam bidang matematika meliputi: dekomposisi, pola dan generalisasi, abstraksi, dan algoritma. Dekomposisi merupakan upaya memecah persoalan menjadi beberapa bagian dan menyelesaikannya satu persatu. Generalisasi dan pola merupakan upaya mengenali adanya keteraturan atau kesamaan karakter kemudian menggunakannya sebagai dasar menyelesaikan masalah. Abstraksi merupakan upaya menerjemahkan masalah ke dalam masalah matematika. Algoritma berupa penggunaan langkah langkah yang runtut dalam menyelesaikan masalah.

Lockwood \& Mooney (2017:15) menyatakan bahwa mengintegrasikan berpikir komputasi di bidang pendidikan memberikan manfaat antara lain: 1) memperbaiki keterampilan berpikir analitis siswa, 2) memungkinkan siswa memiliki pemahaman yang lebih baik tentang pemrograman, bahwa tujuannya adalah memecahkan masalah dan bukan hanya tentang kode, 3) memperbaiki pandangan siswa tentang pemrograman dan mendorong rasa percaya diri mereka, 4) dapat digunakan sebagai indikator yang jelas tentang kesuksesan akademik, hal ini karena skor berpikir komputasi memiliki korelasi yang kuat dengan kesuksesan akademik secara umum. Apabila hal ini diadopsi untuk konteks pembelajaran matematika, berpikir komputasi diperlukan untuk memperbaiki keterampilan analisis siswa dan agar siswa lebih memahami hakekat matematika adalah pemecahan masalah, bukan tentang penggunaan simbol atau keterampilan berhitungnya.

Dengan demikian, berpikir komputasi dalam pembelajaran lebih ditekankan pada proses berpikir untuk memecahkan masalah. Dalam kolaborasinya dengan kemajuan teknologi, maka proses berpikir ini perlu diterjemahkan dalam bahasa mesin yang sifatnya akurat, logis, runtut, terstruktur dan efisien. Disinilah letak pentingnya kemampuan guru dan siswa dalam menyusun algoritma pemecahan masalah. Secara khusus, berpikir komputasi dalam pembelajaran matematika ditekankan pada proses berpikir yang algoritmik dalam memecahkan masalah dan menggunakan matematika sebagai bahasa.

Kemampuan berpikir komputasi perlu dimiliki guru agar mampu untuk membimbing siswanya dalam menyelesaikan masalah secara efektif. Hal ini karena kompetensi dan kinerja guru 
berpengaruh besar, baik secara langsung maupun tidak langsung, terhadap prestasi belajar siswa. Hattie (2003: 3) menyatakan bahwa guru merupakan salah satu faktor dominan yang mempengaruhi prestasi belajar siswa yaitu memberikan sumbangan pengaruh sebesar $30 \%$. Selain itu, guru adalah sumber yang paling penting untuk mengembangkan identitas matematika siswa (Cobb \& Hodge, 2002). Jika guru mengajarkan matematika dengan menekankan pada keterampilan berhitung dan kurang menekankan pada kemampuan berpikir komputasi, maka siswa akan mengembangkan identitas matematikanya sebagai kecakapan berhitung.

Keterampilan berhitung (numeracy) masih terus diperlukan dan penting dikuasai hingga sekarang sebagaimana keterampilan tersebut juga penting dimasa lalu (Crockett, Jukes, \& Churches, 2011:18). Namun seiring kemajuan teknologi saat ini, kemampuan matematika berupa keterampilan berhitung cepat tidak lagi relevan. Kalkulator atau komputer bekerja lebih cepat dengan hasil yang akurat. Siswa akan sulit bersaing hitung cepat dengan kalkulator. Oleh karena itu, orientasi pembelajaran matematika seharusnya bukan lagi melatih kecepatan berhitung tetapi mengembangkan keterampilan berpikir siswa melalui matematika. Salah satunya adalah melatih kemampuan berpikir komputasi melalui matematika.

Penelitian ini merupakan kelanjutan dari penelitian Riset dan Pengembangan Matematika (Risetmatika) jenjang SD yang dilaksanakan pada tahun 2019. Penelitian Risetmatika bertujuan untuk mengidentifikasi kemampuan matematika guru SD ditinjau dari kemampuan matematika dasar, kemampuan berpikir tingkat tinggi (higher order thinking skill-HOTs) dan kemampuan dalam menyelesaikan soal matematika setara USBN. Soal matematika setara USBN disusun berdasarkan soal USBN yang sulit bagi siswa dari hasil tahun 2018 di Propinsi DI Yogyakarta. Penelitian ini dilaksanakan di $22 \mathrm{Kota} / \mathrm{Kabupaten}$ di Indonesia dengan jumlah responden 325 orangguru SD kelas 4, 5, dan 6 atau kelas atas. Khusus responden kemampuan HOTs sebanyak 311 orang guru SD kelas atas.

Hasil penelitian (Tim Peneliti, 2019) menunjukkan bahwa rata-rata skor kemampuan menyelesaikan soal setara USBN jauh lebih rendah dibanding skor matematika dasar dan HOTs sebagaimana disajikan dalam tabel berikut ini.

Tabel 1. Profil Kemampuan Matematika Dasar, Kemampuan dalam Menyelesaikan Soal USBN, dan Kemampuan Berpikir Tingkat Tinggi (HOTS) Guru Kelas SD secara Nasional

\begin{tabular}{llll} 
& \multicolumn{3}{c}{ Kemampuan } \\
\hline Rata-rata Nilai & 54.83 & Penyelesaian Soal USBN & HOTS \\
\hline Nilai Terendah & 0 & 26.06 & 57.40 \\
\hline Nilai Tertinggi & 100 & 0 & 0 \\
\hline Standar Deviasi & 29.79 & 90.00 & 100 \\
\hline
\end{tabular}

Instrumen soal setara USBN terdiri atas 20 butir yang berbentuk pilihan ganda disertai cara penyelesaian atau alasan jawaban. Kompetensi yang diuji disajikan dalam tabel berikut ini.

Tabel 2. Kompetensi Matematika setara USBN yang diuji

\begin{tabular}{|c|c|}
\hline Materi & Kompetensi yang diuji \\
\hline \multirow[b]{2}{*}{ Geometri } & 1. Menentukan banyaknya sumbu simetri pada salah satu bangun datar \\
\hline & 2. Menentukan bangun datar berdasarkan sifatnya \\
\hline \multirow{3}{*}{ Pengukuran } & $\begin{array}{l}\text { 3. Menyelesaikan soal yang berkaitan dengan operasi hitung konversi satuan } \\
\text { panjang yang berbeda }\end{array}$ \\
\hline & $\begin{array}{l}\text { 4. Menyelesaikan soal yang berkaitan dengan operasi hitung konversi satuan } \\
\text { berat yang berbeda. }\end{array}$ \\
\hline & 5. Menentukan luas segitiga atau segiempat \\
\hline \multirow{5}{*}{ Pengukuran } & 6. Menyelesaikan soal yang berkaitan dengan jarak, waktu dan kecepatan \\
\hline & 7. Menentukan luas bagian lingkaran \\
\hline & 8. Menentukan luas bangun datar gabungan \\
\hline & 9. Menyelesaikan masalah terkait luas bangun datar \\
\hline & 10. Menyelesaikan permasalahan terkait skala \\
\hline
\end{tabular}


11. Menyelesaikan permasalahan terkait dengan bangun ruang

\begin{tabular}{ll}
\hline & \multicolumn{1}{c}{ 12. Membaca data yang disajikan dalam bentuk diagram lingkaran } \\
\cline { 2 - 2 } $\begin{array}{l}\text { Pengolahan } \\
\text { Data }\end{array}$ & $\begin{array}{l}\text { Menyelesaikan permasalahan terkait rata-rata dalam kegiatan penilaian di } \\
\text { kelas }\end{array}$ \\
\cline { 2 - 2 } & $\begin{array}{l}\text { 14. Menentukan modus dari data yang diberikan } \\
\text { 15. Menyelesaikan masalah terkait rata-rata hitung dari data yang disajikan dalam } \\
\text { bentuk diagram, tabel, atau data acak }\end{array}$ \\
\cline { 2 - 2 } Pecahan & $\begin{array}{l}\text { 16. Mengurutkan berbagai bentuk pecahan } \\
\text { 17. Menyelesaikan masalah yang berkaitan dengan operasi hitung berbagai } \\
\text { bentuk pecahan }\end{array}$ \\
\hline \multirow{2}{*}{ Bilangan } & 18. Menyelesaikan masalah tentang perbandingan senilai dengan tema tertentu \\
\hline
\end{tabular}

Hasil penelitian Risetmatika tentang kemampuan matematika setara USBN untuk masing-masing materi disajikan dalam tabel berikut ini.

Tabel 3. Rata-rata Nilai Tiap Topik Matematika

\begin{tabular}{ll} 
Materi & Rata-rata Nilai \\
\hline Pecahan & 40,21 \\
\hline Geometri & 29,38 \\
\hline Pengolahan Data & 28,46 \\
\hline Bilangan & 21,69 \\
\hline Pengukuran & 20,51 \\
\hline
\end{tabular}

Pengukuran merupakan materi yang memiliki rata-rata terendah dibandingkan dengan materi lainnya. Salah satu soal pengukuran yang mendapat nilai terendah adalah soal terkait skala. Dari 325 responden, hanya 14 orang yang menjawab benar dan 11 orang diantaranya menjawab tanpa menuliskan langkah penyelesaiannya, 43 orang menjawab salah, dan 268 orang tidak menjawab.

Dalam menyelesaikan masalah matematika, perlu diterapkan strategi pemecahan masalah yang tepat dan efektif. Proses pemecahan masalah dilakukan melalui empat langkah (Polya, 1973), yaitu 1) memahami soal/masalah, 2) merencanakan penyelesaian masalah, 3) menyelesaikan masalah sesuai rencana, 4) memeriksa/mengecek kembali hasil yang diperoleh.

Pemilihan strategi pemecahan masalah menurut tahap Polya ada di urutan kedua setelah memahami masalah. Dengan demikian, pemilihan strategi tergantung dari kebutuhan pemecahan masalah. Strategi pemecahan masalah matematika diantaranya: membuat gambar atau diagram, menemukan pola, membuat tabel, menebak dan memeriksa jawaban, bekerja mundur (melakukan analisis mulai dari jawaban yang dikehendaki), menggunakan masalah yang serupa atau lebih sederhana, menggunakan sudut pandang berbeda, atau menggunakan kontradiksi. Selain beberapa cara ini, pemecah masalah yang handal justru sering mengawali upaya pemecahan masalahnya dengan menggunakan cara coba-coba (trial and error).

Proses pemecahan masalah atau strategi pemecahan masalah ini disebut dengan heuristic.Salado (2018), menggambarkan proses pemecahan masalah sebagai suatu siklus yang meliputi memahami konteks masalah, mengorganisasi masalah, memunculkan rencana penyelesaian dan melaksanakannya, serta verifikasi rencana. Rambally (2017:99) menyatakan bahwa berpikir komputasi juga dipandang sebagai siklus yang meliputi formulasi masalah (abstraksi), mengekspresikan solusi (otomasi), melaksanakan solusi dan evaluasi (analisis). Dibandingkan dengan berpikir komputasi yang melibatkan komputer sebagai alat bantu, proses pemecahan masalah dalam matematika tidak selalu memikirkan otomasi. Namun demikian, terdapat kesamaan dalam hal 
formulasi masalah yang diawali dengan memahami masalah; rencana pemecahan masalah dan pelaksanaannya yang melibatkan analisis dalam berpikir komputasi.

Masalah terkait skala dalam soal setara USBN cukup menantang bagi guru. Untuk itu, perlu dilakukan penelitian lanjutan secara kualitatif untuk mengetahui profil berpikir komputasi guru SD dalam menyelesaikan masalah ini. Penelitian ini bertujuan untuk: 1) menganalisis strategi pemecahan masalah yang digunakan guru dalam menyelesaikan masalah terkait skala, 2) menganalisis berpikir komputasi guru dalam menyelesaikan masalah terkait skala.

\title{
METODE
}

\section{Subjek Penelitian}

Subjek penelitian ini adalah 5 orang guru SD kelas Atas yang dipilih dari 57 orang responden Risetmatika yang menjawab masalah terkait skala. Proses pemilihan dengan cara: 1) mengelompokkan responden berdasarkan benar atau salah dalam menjawab masalah terkait skala, 2) mencermati strategi dan cara menjawab setiap kelompok dan dipilih yang menuliskan proses menjawabnya. Dengan cara ini, diperoleh 5 orang guru yang akan dianalisis berpikir komputasinya. 3 orang yang menjawab benar dan 2 orang yang menjawab salah.

\section{Teknik Pengumpulan Data}

Data dikumpulkan melalui tes berbentuk pilihan ganda dengan alasan atau cara menjawab. Oleh karena penelitian ini merupakan penelitian lanjutan dari penelitian Risetmatika, maka soal tes yang digunakan dalam penelitian ini hanyalah satu soal terkait skala dan menfokuskan analisis pada alasan atau cara guru dalam menjawabnya.

Adapun masalah terkait skala yang diujikan sebagai berikut.

Soal

\begin{abstract}
Siswa kelas VI melakukan kegiatan menggambar di luar kelas. Hasan menggambar menara bertangga dengan skala $1: 150$. Di samping menara terdapat tiang bendera dengan tinggi sebenarnya 4,5 $\mathrm{m}$. Jarak anak tangga pertama dengan permukaan tanah 0,3 $m$ dan jarak anak tangga teratas dengan puncak menara 1,2 m. Banyak anak tangga adalah 76 dengan jarak antar anak tangga sama. Selisih tinggi tiang bendera dengan puncak menara dalam gambar 9,5 cm. Jarak sebenarnya anak tangga ke-25 dengan permukaan tanah adalah ....
\end{abstract}

Strategi pemecahan masalah yang mungkin untuk masalah terkait skala adalah menggambar sketsa dan membuat model matematika. Algoritma penyelesaian masalah tersebut adalah sebagai berikut: 1) konversikan selisih tinggi tiang bendera dengan puncak menara dalam ukuran sebenarnya, 2) menghitung tinggi menara sebenarnya, 3) menghitung panjang tangga yaitu tinggi menara dikurangi jarak anak tangga pertama ke permukaan tanah dikurangi lagi dengan jarak puncak menara ke anak tangga paling atas, 4) menghitung jarak antar anak tangga (panjang tangga dibagi dengan $76-1$ ), dan 5) menghitung jarak sebenarnya anak tangga ke-25 dengan permukaan tanah (24 kali hasil no 5 ditambah 0,3 meter).

\section{Teknik Analisis Data}

Data dianalisis secara kualitatif dengan mengacu pada karakteristik berpikir komputasi yang termuat dalam penyelesaian masalah terkait skala, yaitu dekomposisi dan algoritma, sebagaimana disusun dalam deskripsi sebagai berikut.

Tabel 4. Deskripsi Berpikir Komputasi dalam Penyelesaian Masalah terkait Skala

Kategori

\begin{tabular}{llll}
\hline Unsur & \multicolumn{1}{c}{ Baik } & \multicolumn{1}{c}{ Sedang } & \multicolumn{1}{c}{ Kurang } \\
\hline Dekomposisi & Dipecah menjadi & Dipecah menjadi & Dipecah menjadi \\
Memecah masalah & beberapa submasalah & beberapa submasalah & beberapa submasalah \\
menjadi beberapa & yang: berbeda tetapi & yang: berbeda tetapi & yang: berbeda namun \\
submasalah & saling terhubung, lebih & saling terhubung, lebih & secara keseluruhan \\
\hline
\end{tabular}


mudah diselesaikan, dan secara keseluruhan menyelesaikan masalah utama mudah diselesaikan, tetapi secara keseluruhan tidak efisien dalam menyelesaikan masalah utama Menggunakan tahap yang logis dalam menyelesaikan masalah namun tidak efisien karena misalnya ada duplikasi, ada tahap yang tidak perlu tidak menyelesaikan masalah utama

\begin{tabular}{|c|c|c|c|}
\hline Algoritma & $\begin{array}{l}\text { Menggunakan tahap } \\
\text { yang logis dan efisien }\end{array}$ & $\begin{array}{l}\text { Menggunakan tahap } \\
\text { yang logis dalam } \\
\text { menvelesaikan }\end{array}$ & $\begin{array}{l}\text { Menggunakan tahap } \\
\text { penyelesaian namun } \\
\text { tidak dapat }\end{array}$ \\
\hline $\begin{array}{l}\text { Menggunakan tahap } \\
\text { dalam menyelesaikan } \\
\text { masalah }\end{array}$ & $\begin{array}{l}\text { untuk menyelesaikan } \\
\text { masalah }\end{array}$ & $\begin{array}{l}\text { menyelesaikan } \\
\text { masalah namun tidak } \\
\text { efisien karena misalnya } \\
\text { ada duplikasi, ada } \\
\text { tahap yang tidak perlu }\end{array}$ & $\begin{array}{l}\text { tidak dapat } \\
\text { memecahkan masalah }\end{array}$ \\
\hline
\end{tabular}

Deskripsi berpikir komputasi tersebut diadaptasi dari computational thinking rubrics (https://cpb-usw2.wpmucdn.com/sites.udel.edu/dist/4/8672/files/2018/12/Computational-Thinking-Rubric$2 \mathrm{ktkkgv} . p d f)$ dengan penyederhanaan.

\section{HASIL DAN PEMBAHASAN}

\section{Strategi Penyelesaian Masalah Terkait Skala}

Dari 14 orang yang menjawab masalah terkait skala dengan benar, ada 3 orang yang menuliskan langkah penyelesaiannya, dan dari 43 orang yang menjawab salah, ada 2 orang yang menuliskan langkah penyelesaiannya. Lima orang tersebut, inisial guru A, B, C, D, dan E, dianalisis dengan hasil sebagai berikut:

\section{Analisis Strategi yang Menjawab Benar}

\section{Guru A:}

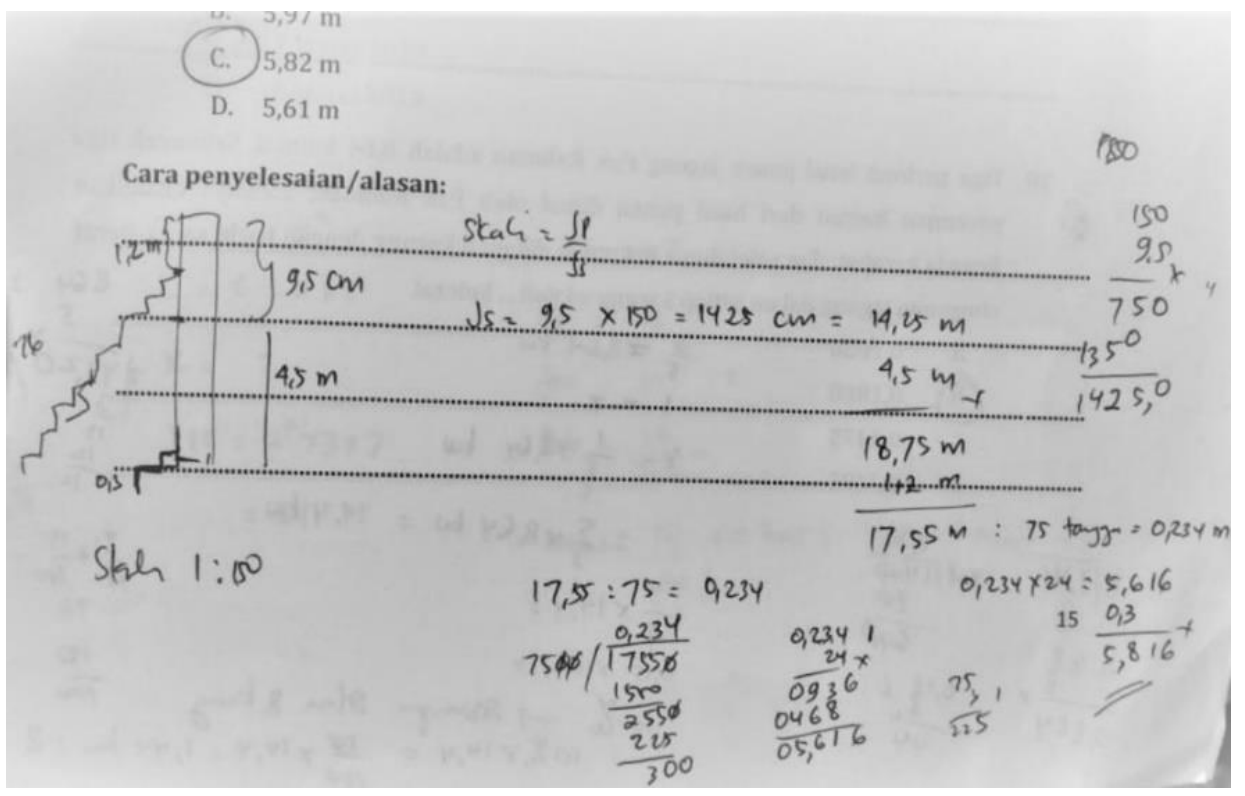

\section{Gambar 1. Pekerjaan Guru A}

Strategi yang digunakan guru A untuk memahami masalah adalah menggambar sketsa. Proses selanjutnya, mengonversi selisih tinggi tiang bendera dengan puncak menara. Langkahnya tepat, tapi penulisan kalimat matematikanya kurang tepat. Guru A menuliskan $J s=9,5 \times 150$. Tidak ada pendefinisian $J_{S}$ itu apa. Selanjutnya guru A bahkan tanpa menuliskan model/kalimat matematikanya, melainkan langsung melakukan operasi hitung terhadap data yang ada. 


\section{Guru B:}
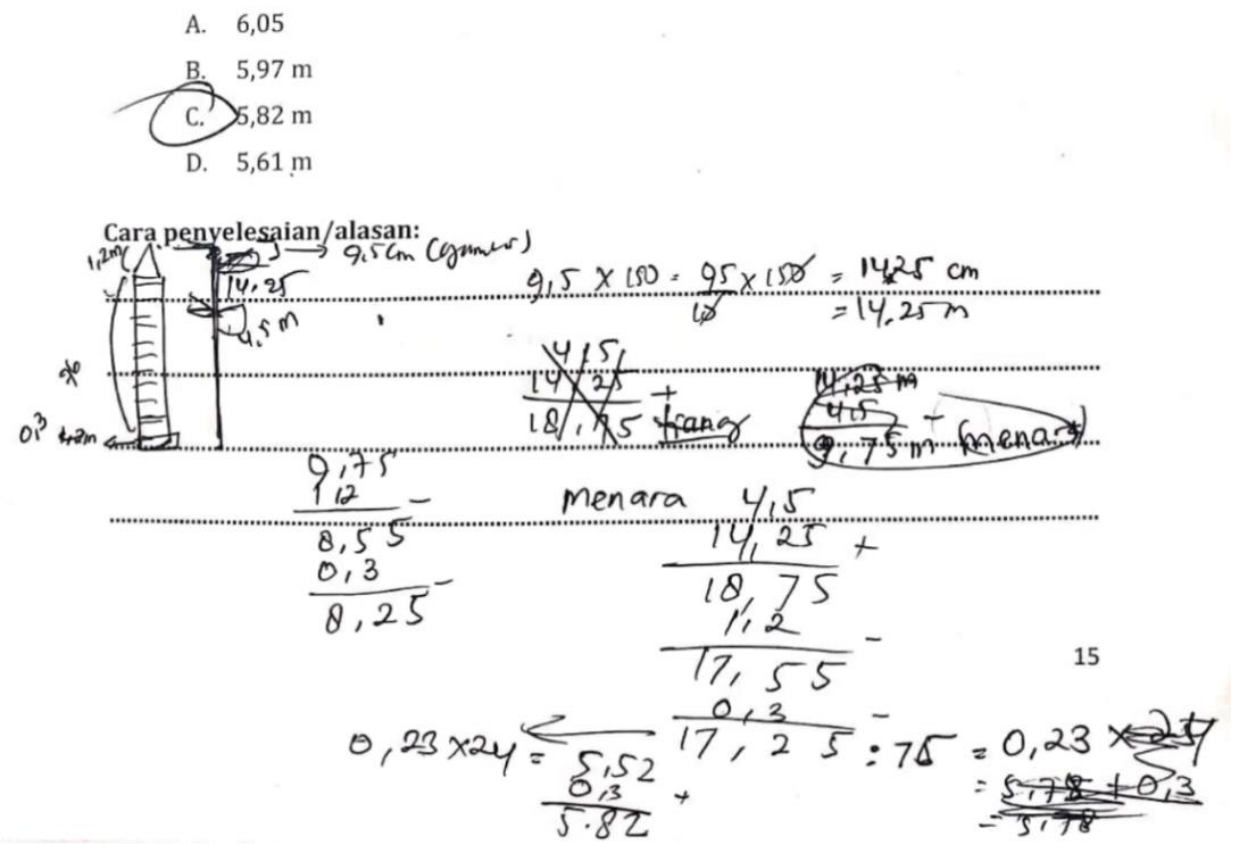

Gambar2. Pekerjaan Guru B

Guru B juga membuat gambar/sketsa untuk membantu memahami masalah. Pembuatan sketsa yang seadanya, cukup mempresentasikan informasi yang ada. Pada jawaban ini, Guru B mengetahui hubungan antar informasi yang ada untuk menyelesaikan masalah, tapi tidak terlihat sama sekali penulisan model/kalimat matematikanya, melainkan langsung mengoperasikan bilangan-bilangan sebagai wakil dari data yang ada.

\section{Guru C:}

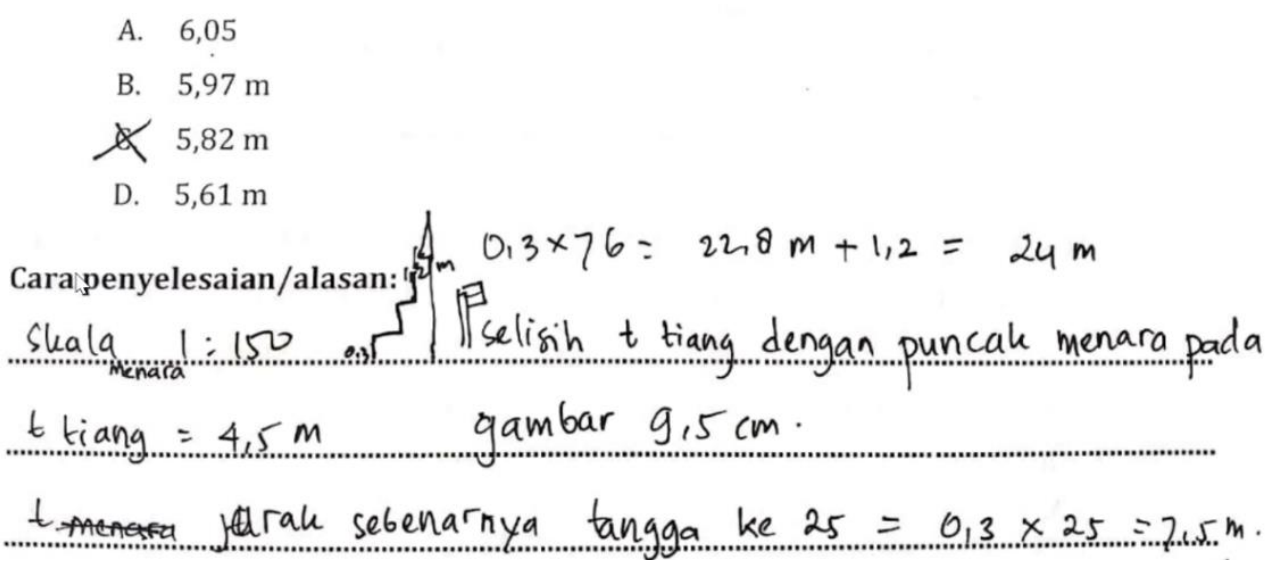

Gambar 3. Pekerjaan Guru C

Guru C ini juga menggambar sketsa dan menuliskan skala. Hanya saja jika diperhatikan, sketsa yang dibuat tidak cukup mempresentasikan informasi-informasi yang ada. Ketika menggambar sketsa, Guru $\mathrm{C}$ hanya menuliskan jarak anak tangga pertama dengan permukaan tanah, dan jarak anak tangga teratas dengan puncak menara. Informasi yang lain, yaitu selisih tinggi tiang bendera dengan puncak menara dan tinggi tiang bendara ditulis tersendiri. Terdapat satu kalimat matematika yang tertulis, yaitu jarak sebenarnya tangga ke $25=0,3 \times 25=7,5 \mathrm{~m}$. Namun logika berpikir atas kalimat matematika ini keliru, Guru C kelihatan tidak memahami soal. 


\section{Analisis Strategi yang Menjawab Salah}

\section{Guru D:}

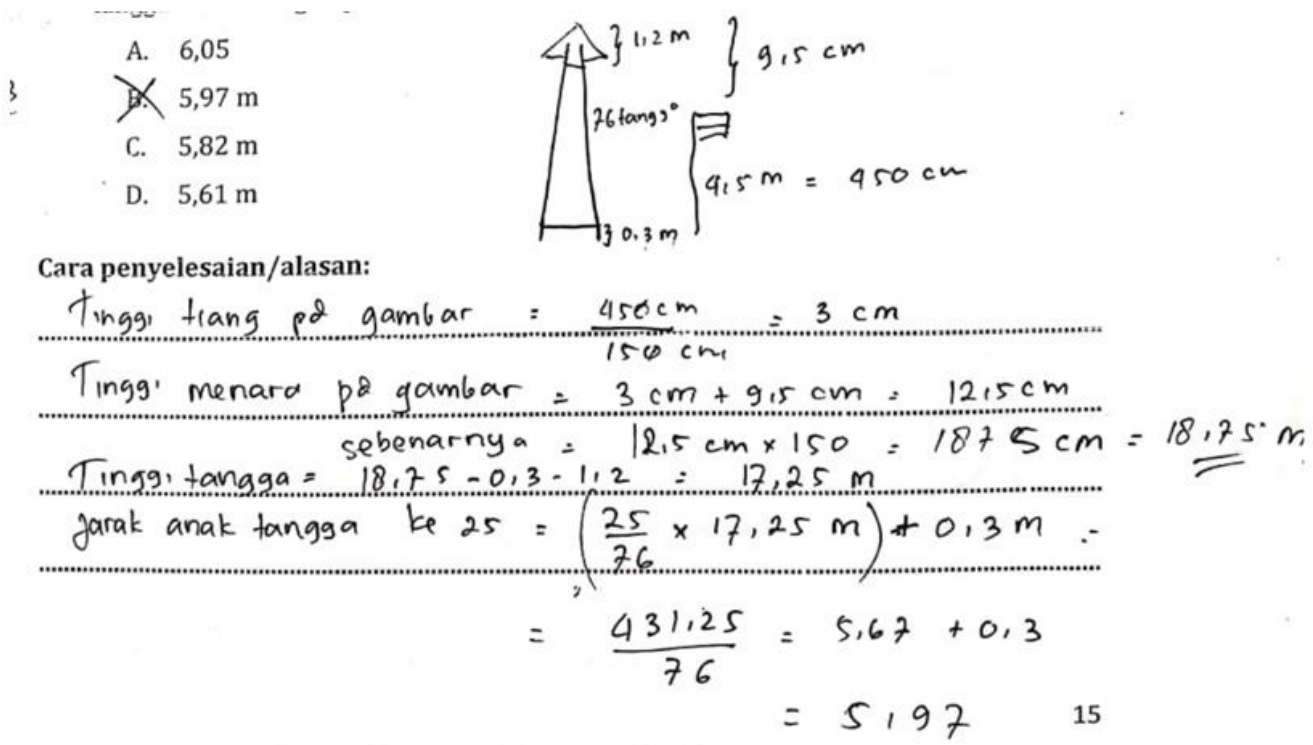

Gambar 4. Pekerjaan Guru D

Strategi penyelesaian guru D juga dengan menggambar sketsa. Guru D menuliskan informasi apa saja yang diketahui dengan membubuhkan ukuran pada gambar. Dari jawaban terlihat bahwa hubungan antara informasi dengan permasalahan sudah dinyatakan ke dalam kalimat matematika. Dapat dikatakan guru ini menuliskan model matematikanya. Namun, kalimat matematika ditulisnya tanpa mengubah informasi atau data yang diketahui ke dalam simbol.

Dalam membuat model matematika, data yang diketahui dapat didefinisikan dengan simbol misal $b$ $=$ tinggi tiang bendera, $c=$ jarak anak tangga pertama dengan permukaan tanah, $d=$ jarak anak tangga teratas dengan puncak menara, $d=$ selisih tinggi tiang bendera dengan puncak menara, $p=$ tinggi menara dan seterusnya. Guru D ini tidak melakukan hal tersebut, sehingga tidak ada kejelasan kenapa ketika mencari tinggi tiang pada gambar harus dibagi dengan 150 karena skala juga tidak dituliskan. Jika sudah didefinisikan maka tinggi menara pada gambar dapat dituliskan dengan $p=b+d=$ $3+9,5=12,5$.

\section{Guru E:}

Strategi yang dilakukan guru E ini mirip dengan Guru A dan Guru B yaitu menggambar sketsa dan mengoperasikan bilangan-bilangan/data yang ada, tanpa menuliskan model/kalimat matematikanya.
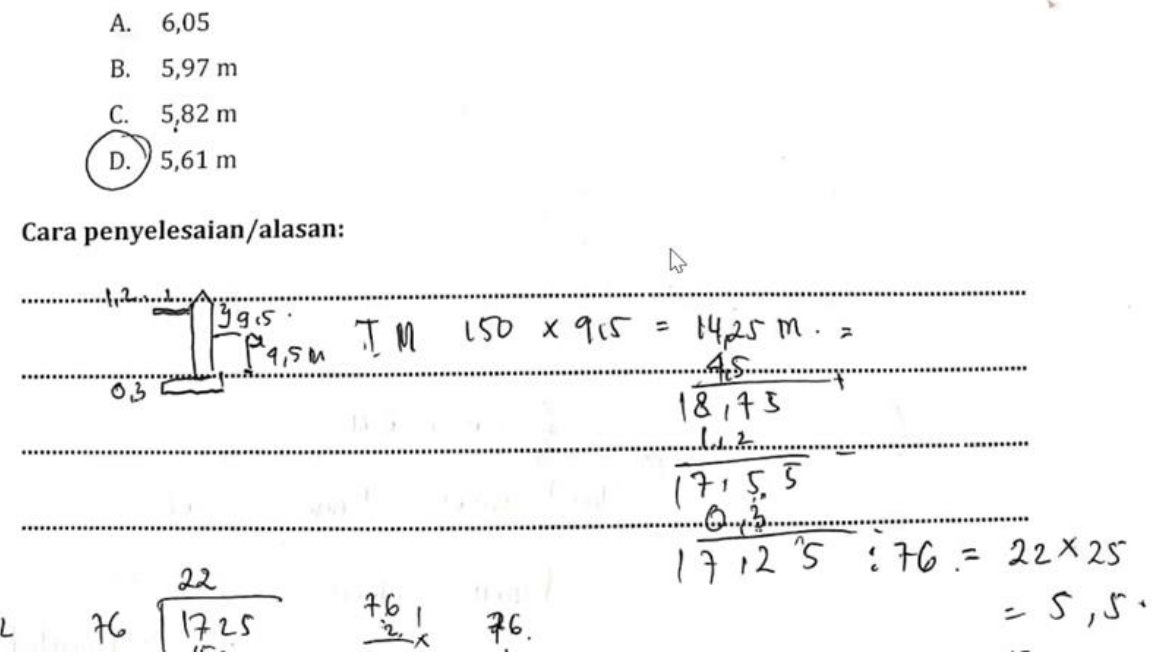


\section{Gambar 5. Pekerjaan Guru E}

Ditinjau dari sketsa yang digambar, sketsa Guru A, B, D dan E sejenis, meski gambarnyatidak sama persis tapi sudah merepresentasikan informasi-informasi yang diketahui. Adapun sketsa yang digambar Guru $\mathrm{C}$ belum cukup mempresentasikan informasi yang diberikan, karena hanya menuliskan jarak anak tangga pertama dengan permukaan tanah dan jarak anak tangga teratas dengan puncak menara.

Hal yang perlu mendapat perhatian selanjutnya adalah pentingnya menampilkan model matematika dalam setiap pemecahan masalah, karena hal ini terkait dengan kedudukan matematika sebagai bahasa dan bukan hanya alat hitung. Langkah awal membuat model matematika yang tak lain adalah menuliskan informasi yang diketahui sudah terwakilkan ketika guru menggambar sketsa beserta ukuran-ukurannya. Namun, selanjutnya guru tidak mengubah permasalahan ke dalam kalimat matematika, melainkan langsung mengoperasikan bilangan yang ada, sehingga apa yang dituliskan kurang komunikatif.

\section{Profil Berpikir Komputasi dalam Menyelesaikan Masalah terkait Skala}

Permasalahan utama yang harus diselesaikan dalam masalah terkait skala adalah mencari jarak sebenarnya anak tangga ke-25 dengan permukaan tanah. Berdasarkan informasi-informasi yang diberikan, maka untuk menjawab permasalahan utama ini, permasalahan dibagi menjadi beberapa bagian dan diselesaikan satu per satu secara bertahap. Tahapan dalam menyelesaikan setiap bagian masalah juga harus runtut.

\section{Analisis Jawaban Benar}

Hasil analisis terhadap 3 jawaban benar guru, diperoleh bahwa ketiga guru tersebut memecah beberapa bagian dan menyelesaikannya satu persatu secara bertahap. Dalam proses mengoperasikan bilangan terlihat tahapan sebagai berikut: 1) mengonversikan selisih tinggi tiang bendera dengan puncak menara ke ukuran sebenarnya, 2) mencari tinggi menara, 3) menghitung panjang tangga, 4) menghitung jarak antar anak tangga, 5) menghitung jarak anak tangga ke-25 dengan permukaan tanah.

\section{Guru A:}

Guru A mengonversikan selisih tinggi tiang bendera dengan puncak menara ke ukuran sebenarnya, yaitu $(9,5 \times 150) \mathrm{cm}=1425 \mathrm{~cm}=14,25 \mathrm{~m}$. Tahap berikutnya mencari tinggi menara, yaitu $(14,25+4,5) m=18,75 m$. Setelah mencari tinggi menara, Guru A menghitung panjang tangga, yaitu $(18,75-1,2) m=17,55 \mathrm{~m}$. Dalam hal ini seharusnya panjang tangga diperoleh dari mengurangkan tinggi menara dengan jarak anak tangga pertama ke permukaan tanah dan jarak puncak menara ke anak tangga paling atas. Namun yang dilakukan guru ini hanya mengurangkan tinggi menara dengan jarak puncak menara ke anak tangga paling atas. Berikutnya, guru A menghitung jarak antar anak tangga, yaitu $17,55 m \div 75=0,234 m$. Dalam perhitungan ini pembaginya adalah 75 (banyak anak tangga dikurangi satu). Dan yang terakhir menghitung jarak anak tangga ke-25 dengan permukaan tanah. Guru A ini melakukannya dengan dua tahap, yaitu $(0,234 \times 24)=5,516$; kemudian menambahkan hasilnya dengan 0,3 , yaitu 5,616 + 0,3 = 5,816 .

Berdasarkan jawaban di atas, secara dekomposisi, Guru A sudah membagi permasalahan menjadi beberapa bagian dan menyelesaikannya. Secara algoritma, dapat dikatakan Guru A sudah melakukan dengan benar, hanya saja terdapat kekeliruan perhitungan di dalamnya. Pertama, untuk menghitung jarak anak tangga ke-25, yang dikalikan dengan jarak antar anak tangga adalah 24, bukan 25 . Kedua, hasil perhitungan 5,616+0,3 tidak tepat, semestinya 5,916. Kekeliruan perhitungan yang menghasilkan 5,816 ini menyebabkan guru A menjawab pilihan C, karena jika dibulatkan hasilnya 5,82 .

\section{Guru B:}

Tahapan yang dilakukan oleh guru B sama dengan guru A, yaitu 1) mengonversikan selisih tinggi tiang bendera dengan puncak menara ke ukuran sebenarnya, yaitu $(9,5 \times 150) \mathrm{cm}=1425 \mathrm{~cm}=$ $14,25 \mathrm{~m} ; 2$ ) mencari tinggi menara, yaitu $4,5+14,25=18,75 ; 3$ ) menghitung panjang tangga, guru B menghitung panjang tangga dalam dua tahap, yaitu $18,75-1,2=17,55$; selanjutnya $17,55-$ 
$0,3=17,25 ; 4)$ menghitung jarak antar anak tangga, yaitu $17,25 \div 75=0,23$. Dalam perhitungan ini pembaginya adalah 75 (banyak anak tangga dikurangi satu); 5) menghitung jarak anak tangga ke25 dengan permukaan tanah. Guru B melakukannya dengan dua tahap, yaitu $(0,23 \times 24)=5,52$; kemudian menambahkan hasilnya dengan 0,3 , yaitu $5,52+0,3=5,82$.

Secara dekomposisi, Guru B sudah membagi ke dalam beberapa permasalahan dan menyelesaikan dengan benar. Tahapan algoritmanya juga sudah runtut dan lengkap.

\section{Guru C:}

Setelah menggambar sketsa dan menuliskan skala, tidak ada tahapan mengonversi selisih tinggi tiang bendera dengan puncak menara ke ukuran sebenarnya, mencari tinggi menara, menghitung panjang tangga, dan menghitung jarak antar anak tangga. Guru tersebut langsung menghitung jarak anak tangga ke-25 terhadap permukaan tanah dengan cara mengalikan jarak anak tangga pertama dari permukaan tanah dengan bilangan 25, dan menghasilkan jawaban 7,5 $\mathrm{m}$ (lihat gambar 3).

Dari proses tersebut terlihat bahwa secara dekomposisi, Guru C tidak membagi ke dalam beberapa permasalahan secara logis. Guru C juga melewati beberapa prosedur algoritma. Dari hasil perhitungan yang dilakukan menunjukkan Guru $\mathrm{C}$ menjawab dengan asal dan secara kebetulan pilihan jawabannya benar.

\section{Analisis Jawaban Salah}

\section{Guru D:}

Guru D menggunakan strategi pemecahan masalah dengan menggambar sketsa dan membuat kalimat matematika. Guru D terlihat membagi permasalahan ke beberapa bagian dan menyelesaikannya, tetapisecara algoritmik terdapat prosedur yang terlewatkan oleh guru C. Guru ini tidak mengonversi selisih tinggi tiang bendera dengan puncak menara ke ukuran sebenarnya, melainkan mengonversi tinggi tiang bendera sebenarnya ke dalam gambar, kemudian menentukan tinggi menara dalam gambar (lihat gambar 4). Setelah itu baru mengonversi tinggi menara ke dalam ukuran sebenarnya, dilanjutkan mencari tinggi tangga.

Jika dicermati, ketika mencari jarak anak tangga ke-25 dari permukaan tanah, dalam perhitungannya sudah termasuk mencari jarak antar anak tangga, hanya kekeliruannya adalah pembaginya adalah banyak anak tangga, yaitu 76. Kekeliruan yang lain adalah kemudian mengalikannya dengan 25, bukan 24 (anak tangga ke-25 dikurangi 1), sehingga jawaban yang diperoleh 5,97.

\section{Guru E:}

Tak berbeda dengan yang lain, sebagai permulaan Guru E menggambar sketsa. Dari jawabannya terlihat bahwa Guru E juga membagi permasalahan ke dalam beberapa bagian. Secara algoritmik, Guru E melakukan dengan runtut dan lengkap. Kekeliruan terjadi ketika mencari jarak antar anak tangga, karena membagi panjang/tinggi tangga dengan banyak tangga $(17,25: 76)$, seharusnya dibagi dengan 75 . Hal ini mengakibatkan perhitungan selanjutnya juga keliru.

Berdasarkan analisis terhadap jawaban yang disertai langkah penyelesaian tadi, secara umum diperoleh bahwa Guru A, B, D dan E kemampuan dekomposisinya termasuk kategori baik dan Guru C termasuk kategori kurang. Adapun kemampuan algoritma Guru A, B, dan E termasuk kategori baik, Guru D termasuk kategori sedang, dan Guru C termasuk kategori kurang. Kesalahan dalam menjawab terjadi karena dalam menyelesaikan tiap tahap kurang teliti dalam menghitung atau kurang berpikir logis tentang hubungan antar informasi.

\section{KESIMPULAN DAN SARAN.}

\section{Kesimpulan}

1. Strategi yang digunakan oleh guru dalam menyelesaikan permasalahan terkait skala adalah membuat gambar/sketsa yang dilengkapi dengan informasi/data yang diberikan. Namun, model/kalimat matematika belum ditampilkan dengan komunikatif.

2. Dalam unsur dekomposisi, guru sudah memecah permasalahan ke dalam bagian-bagian permasalahan yang berbeda dan saling terhubung, kemudian menyelesaikannya satu per satu secara bertahap sehingga dapat menyelesaikan masalah utama. Secara algoritmik guru sudah 
melakukan penyelesaian secara bertahap dengan tahapan yang logis dan efisien untuk menyelesaikan masalah. Kesalahan terjadi karena keliru menghitung atau kurang berpikir logis Saran

dalam menafsirkan hubungan antar informasi.

1. Perlu dilatihkan, khususnya kepada siswa, keterampilan dalam menggunakan strategi membuat model matematika yaitu dengan menyatakan permasalahan dalam kalimat sehari-hari ke dalam kalimat matematika.

2. Perlu dibiasakan, khususnya kepada siswa, keterampilan dalam memecah permasalahan dengan cermat dan berpikir logis agar submasalah mengarah pada penyelesaian masalah utama. Kembangkan algoritma secara runtut dan efisien, sehingga tidak melompat-lompat atau ada tahap yang tidak perlu.

\section{DAFTAR PUSTAKA}

Cobb, P., \& Hodge, L. L. (2002). A relational perspective on issues of cultural diversity and equity as they play out in the mathematics classroom. Mathematical Thinking and Learning, 4, p. 249 284

Crockett, L., Jukes, I., \& Churches, A. (2011). Literacy is not enough: $21^{\text {st }}$-century fluencies for the digital age. Washington DC: Corwin A Sage Company.

Denning, P.J. (2009). Beyond computational thinking. Communication of The ACM, 52(6), 28-30 DOI: http://doi.acm.org/10.1145/1516046.1516054

Hattie, J. (2003). Teachers Make a Difference: What is the research evidence?.Australian Council for Educational Research Annual Conference on: Building Teacher Quality

Ioannidou, A., et al. (2011). Computational thinking patterns. Makalah pada Annual Meeting of the American Educational Research Association (AERA) in the Division C - Learning and Instruction / Section 7: Technology Research symposium "Merging Human Creativity and the Power of Technology: Computational Thinking in the K-12 Classroom".

ISTE International Society for Technology in Education. (2007). National educational technology standards for students (NET) $2^{\text {nd }}$ Edition. http://www.iste.org/standards/nets-forstudents.aspx

Lockwood, J. \& Mooney, A. (2014). Computational thinking in education: where does it fit? A systematic literary review. Kildare: Maynooth University https://arxiv.org/ftp/arxiv/papers/1703/1703.07659.pdf Diakses pada tanggal 27 April 2020 jam 09.30 .

Mitchelmore, M. \& White, P. (2004). Abstraction in Mathematics and Mathematics Learning. Makalah dalam Proceedings of The $28^{\text {th }}$ Conference of The International Group for The Psychology of Mathematics Education, Vol 3, pp329-336 Tanggal 14 -18 Juli. Bergen: Bergen University College.

Polya, G. (1973). How to solve it: A new aspect of mathematical method. Princeton, NJ: Princeton University Press.

Pyzara, A. (2014). Creating an Algorithm of A Real-Life Situation as A Form of Mathematical Modelling. Didactics of mathematics, 11(15), 25-42.

Rambally. (2017). Integrating computational thinking in discrete structures. Pada Rich, P.J \& Hodges, C.B (Editor) Emerging Research, practice, and policy on computational thinking, Educational Communication and Technology: Issues and Innovation, DOI 10.1007/978-3-31952691-1_7.

Rani, M. (2013). Mathematics As A World Language Or Mathematics As A Collection Of Dialects?. International Journal of Engineering and Management Research, 3(3), 56-63.

Salado, A. (2018). A Mathematical Model of Verification Strategies. Systems Engineering, 21(6) https://doi.org/10.1002/sys.21463

Tim Peneliti. (2019). Laporan Penelitian Riset dan Pengembangan Matematika: Profil Kemampuan Matematika Guru dalam Menyelesaikan Soal UN/USBN, Matematika Dasar dan HOTS. Yogyakarta: PPPPTK Matematika. 